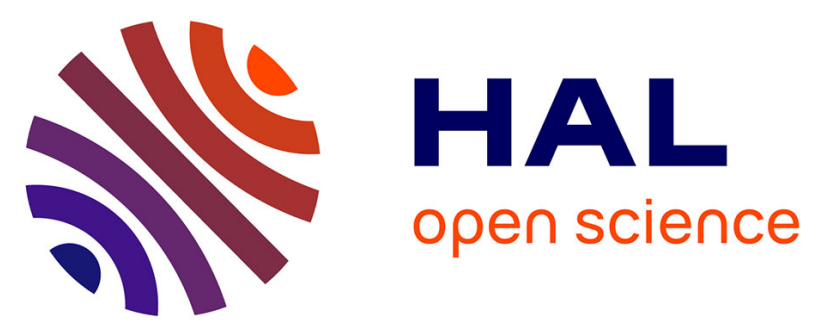

\title{
Vegetation composition controls temperature sensitivity of CO2 and CH4 emissions and DOC concentration in peatlands
}

\author{
Fabien Leroy, Sébastien Gogo, Christophe Guimbaud, Léonard \\ Bernard-Jannin, Zhen Hu, Fatima Laggoun-Défarge
}

\section{To cite this version:}

Fabien Leroy, Sébastien Gogo, Christophe Guimbaud, Léonard Bernard-Jannin, Zhen Hu, et al.. Vegetation composition controls temperature sensitivity of $\mathrm{CO} 2$ and $\mathrm{CH} 4$ emissions and DOC concentration in peatlands. Soil Biology and Biochemistry, 2017, 107, pp.164-167. 10.1016/j.soilbio.2017.01.005 . insu-01440176

\section{HAL Id: insu-01440176 \\ https://hal-insu.archives-ouvertes.fr/insu-01440176}

Submitted on 19 Jan 2017

HAL is a multi-disciplinary open access archive for the deposit and dissemination of scientific research documents, whether they are published or not. The documents may come from teaching and research institutions in France or abroad, or from public or private research centers.
L'archive ouverte pluridisciplinaire HAL, est destinée au dépôt et à la diffusion de documents scientifiques de niveau recherche, publiés ou non, émanant des établissements d'enseignement et de recherche français ou étrangers, des laboratoires publics ou privés.

\section{(ㅇ)(1) $\$$}

Distributed under a Creative Commons Attribution - NonCommercial - NoDerivatives $\mid 4.0$ 


\section{Vegetation composition controls temperature sensitivity of $\mathrm{CO}_{2}$ and $\mathrm{CH}_{4}$ emissions and DOC concentration in peatlands}

Fabien Leroy ${ }^{1,2,3^{*}}$, Sébastien Gogo ${ }^{1,2,3}$, Christophe Guimbaud ${ }^{4,5}$, Léonard Bernard-Jannin ${ }^{1,2,3}$, Zhen $\mathrm{Hu}^{6}$, Fatima Laggoun-Défarge $\mathrm{e}^{1,2,3}$

${ }^{1}$ Université d'Orléans, ISTO, UMR 7327, 45071, Orléans, France

${ }^{2}$ CNRS, ISTO, UMR 7327, 45071 Orléans, France

${ }^{3}$ BRGM, ISTO, UMR 7327, BP 36009, 45060 Orléans, France

${ }^{4}$ Université d'Orléans, LPC2E, UMR 7328, 45071, Orléans, France

${ }^{5}$ CNRS, LPC2E, UMR 7328, 45071, Orléans, France

${ }^{6}$ School of Environmental Science and Engineering, Shandong University, Jinan, China

*Corresponding author, tel: + 332384948 58, email: fabien.leroy@univ-orleans.fr

Keywords: Ecosystem respiration, dissolved organic matter, soil temperature, Q10, Molinia, Sphagnum mosses.

Type of paper: Short Communication

\section{Highlights}

- The occurrence of Molinia caerulea increases $\mathrm{CO}_{2}$ and $\mathrm{CH}_{4}$ emissions in Sphagnumdominated peat mesocosms.

- DOC concentration decreases with the presence of Molinia caerulea compared to Sphagnum with no Molinia caerulea.

- $\mathrm{CO}_{2}$ and $\mathrm{CH}_{4}$ emissions and DOC concentration are strongly related to soil temperature.

- Vegetation cover modifies the sensitivity of $\mathrm{CO}_{2}$ and $\mathrm{CH}_{4}$ emissions and DOC concentration to soil temperature.

- Molinia caerulea could affect the composition of the methanogenic communities.

\section{Abstract}


Plant community modification may play an important role in peatlands' carbon balance. We investigated how Molinia caerulea altered $\mathrm{CO}_{2}$ and $\mathrm{CH}_{4}$ fluxes and DOC concentration as well as their sensitivity to water table level, air and soil temperature in Sphagnum-dominated peat mesocosms. The presence of Molinia caerulea significantly increased $\mathrm{CO}_{2}$ and $\mathrm{CH}_{4}$ emissions compared to Sphagnum and decreased the DOC concentration. The rise in temperature exponentially increased DOC as well as $\mathrm{CO}_{2}$ and $\mathrm{CH}_{4}$ emissions. Molinia caerulea decreased the temperature sensitivity of $\mathrm{CO}_{2}$ emissions, suggesting the presence of a more labile substrate (root exudates), while it increased the temperature sensitivity of $\mathrm{CH}_{4}$ emissions, suggesting a possible change in methanogenic communities. Our study highlights a strong impact of vegetation change on $\mathrm{C}$ dynamics in peatlands. 
Peatlands act as a global major carbon (C) store. They contain between 15 to $30 \%$ of the world soil C in only 3\% of the global land area (Turunen et al., 2002; Gorham, 1991). The Csink function of boreal peatlands results from particular environmental conditions (waterlogging, acidic soil and low temperature) and specific vegetation, i.e. Sphagnum mosses. However, global change is expected to modify plant species composition in northern Sphagnum peatlands, with an increase in vascular plants (e.g. graminoids) to the detriment of Sphagnum mosses (Dieleman et al., 2015; Buttler et al., 2015). Disturbed peatlands represent a large potential source of $\mathrm{CO}_{2}$ and $\mathrm{CH}_{4}$ to the atmosphere and of dissolved organic carbon (DOC) export to rivers (Limpens et al., 2008). Thus, understanding the feedback between vegetation change and $\mathrm{C}$ fluxes in peatlands is required to predict the future of the peatland $\mathrm{C}$ budget. The response of $\mathrm{CO}_{2}$ and $\mathrm{CH}_{4}$ emissions and DOC concentration ([DOC]) to abiotic control is well documented (Clark et al., 2009; Pypker et al., 2013). Nevertheless, studies on the sensitivity of $\mathrm{C}$ fluxes and $[\mathrm{DOC}]$ to abiotic factors in a context of vegetation change are lacking. Our aim was to assess to what extent $\mathrm{CO}_{2}$ and $\mathrm{CH}_{4}$ emissions and [DOC] sensitivities to abiotic factors in Sphagnum peat mesocosms could be modulated by the occurrence of vascular plants. The presence of graminoids in Sphagnum mesocosms is expected to change C fluxes through a more efficient $\mathrm{C}$ uptake that allocates $\mathrm{C}$ to the above- and belowground parts of the plant. Vascular plants have an extensive root systems, in comparison to Sphagnum rhizoids, able to exudate newly produced labile organic compounds (e.g. glucose; Saarnio et al., 2004; Fenner et al., 2007). According to Arrhenius function, the degradation rate of these compounds has a lower sensitivity to temperature than recalcitrant organic matter (Davidson and Janssens, 2006). Thus, Sphagnum peat mesocosms invaded by Molinia caerulea was sampled to investigate the three following hypotheses:

(i) the presence of Molinia caerulea will increase the [DOC] due to a higher root exudate production compared to Sphagnum spp., 
(ii) these labile exudates will be rapidly consumed by microbial communities and will enhance both $\mathrm{CO}_{2}$ and $\mathrm{CH}_{4}$ emissions,

(iii) as the $\mathrm{C}$ source will be more labile, the sensitivity to temperature of the $\mathrm{C}$ fluxes will decrease compared to recalcitrant $\mathrm{C}$ (with higher activation energies).

Twelve peat mesocosms (depth and diameter: $30 \mathrm{~cm}$ ) were collected in March 2015 in La Guette peatland (France). The studied site is an acidic fen invaded by Molinia caerulea, a graminoid plant invading numerous peatlands (Tomassen et al., 2003; Gogo et al., 2011). The mesocosms were buried outside and surrounded with a tarpaulin containing water from the peatland. Air and soil temperature at 5 and $20 \mathrm{~cm}$ depth were monitored in each mesocosm. The mesocosms were separated into 2 treatments: 6 containing only Sphagnum rubellum ('Sphagnum' cores) and 6 containing Sphagnum rubellum and Molinia caerulea ('Molinia' cores). Molinia caerulea started to grow in May and increased up to $60 \%$ of mesocosms on average until its senescence in November (see supplementary material).

Measurements were performed between two to eight times per month, from May 2015 to April 2016. Ecosystem Respiration (ER) was measured during 5 min using a closed chamber equipped with a GMP343 Vaisala (D’Angelo et al., 2016). $\mathrm{CH}_{4}$ emissions were measured during 15 min using the SPIRIT, a portable infrared laser spectrometer (Guimbaud et al., 2011). Water table level (WTL) was manually measured in each mesocosm piezometer. Water was collected from the piezometer to measure [DOC] with a Shimadzu TOC-5000 analyzer. All measurements were performed in the same day and were related to WTL, air and soil temperature at 5 and $20 \mathrm{~cm}$ depth with exponential regression. $\mathrm{R}^{2}$ from exponential regressions were calculated after a logarithmic transformation (linearization of the date). Temperature sensitivity was expressed through the temperature coefficient $\left(\mathrm{Q}_{10} ;\right.$ eq. 1$)$, and energy of activation ( $E_{a}$, eq. 2): 
$\mathrm{k}_{1}$ and $\mathrm{k}_{2}$ are rates at two observed temperatures $\mathrm{T}_{1}$ and $\mathrm{T}_{2}$.

$\mathrm{k}=\mathrm{A} \cdot \mathrm{e}^{(-\mathrm{Ea} / \mathrm{RT})}$

eq. 2

$\mathrm{k}$ is the reaction rate coefficient, $\mathrm{A}$ is the pre-exponential factor, $\mathrm{R}$ is the ideal gas constant and $\mathrm{T}$ is the temperature in Kelvin.

One-way ANOVAs with repeated measures were used to compare Molinia to Sphagnum cores.

Throughout the measurements, environmental conditions did not differ significantly between Sphagnum and Molinia cores other than the WTL which was $2.4 \mathrm{~cm}$ higher in Sphagnum cores than in the Molinia ones (Table I). WTL ranged from $2.5 \mathrm{~cm}$ to $17 \mathrm{~cm}$ (Fig 1a). Air temperature ranged from $0^{\circ} \mathrm{C}$ in January to $30^{\circ} \mathrm{C}$ in July (Fig 1b). Soil temperature at 5 and $20 \mathrm{~cm}$ depth varied from $2.3^{\circ} \mathrm{C}$ and $5^{\circ} \mathrm{C}$ in January to $27.3^{\circ} \mathrm{C}$ and $25.7^{\circ} \mathrm{C}$ in July, respectively (Fig 1c and 1d).

[DOC] were significantly lower in Molinia cores compared to Sphagnum ones (Table I, Fig 2c), which disproves our first hypothesis but supports the mechanisms proposed by Freeman et al. (2004) who suggested that labile DOC release, through root exudates, stimulates microbial activity and enhances the degradation of organic matter, in particular the DOC fraction. Mimics of roots exudates have been revealed to enhance microbial biomass in peat soil (Basiliko et al., 2012), that might, with Molinia caerulea occurrence, trigger a real priming effect leading to an increase of DOC consumption.

Furthermore, in contradiction to our third hypothesis, the presence of Molinia increased the [DOC] sensitivity to soil temperature ( $\mathrm{Q}_{10}, \mathrm{E}_{\mathrm{a}}$, Table II and Fig 2c). The $\mathrm{Q}_{10}$ values obtained were higher than those found by Freeman et al. (2001; $\left.\mathrm{Q}_{10}=1.36\right)$ but lower than those found by Clark et al. (2009; $\mathrm{Q}_{10}=1.84$ and 3.53 under anaerobic and aerobic conditions, respectively). As postulated by the latter authors, we showed that vegetation cover plays an important role in 
the $[\mathrm{DOC}]$ and its sensitivity to soil temperature. Further studies on the DOC and vegetation relationship are essential to determine how vegetation change may alter this $\mathrm{C}$ pool.

$\mathrm{CO}_{2}$ and $\mathrm{CH}_{4}$ emissions were higher in the presence of Molinia caerulea comparing to Sphagnum, showing an average increase of 2.4 and 3.1 fold, respectively (Table I, Figure 2a and b). Similar observations have already been reported in peatlands with graminoids (e.g. Armstrong et al. 2015). The greatest $\mathrm{CH}_{4}$ emissions were observed with Molinia occurrence, at the same time with an increase of the thickness of aerobic zone, which opposes with the general association of $\mathrm{CH}_{4}$ emissions under anaerobic conditions. Such potential effect could be compensated with the fueling of methanogens in anaerobic peat by the root exudates, already related to the difference of $\mathrm{CH}_{4}$ production among plants species (Koelbener et al., 2010). Furthermore, variations of $\mathrm{CH}_{4}$ emissions are also controlled by the plant community and its ability to transport $\mathrm{CH}_{4}$ (Schimel, 1995) and their potential for rhizospheric oxidation (Ström et al., 2005). If root exudates fuel the microbial communities, the $\mathrm{C}$ flux sensitivity to temperature is expected to decrease (Davidson and Janssens, 2006). This hypothesis was confirmed by the ER results: the presence of Molinia decreased the ER sensitivity to temperature (Table II). However, this did not hold for $\mathrm{CH}_{4}$. The temperature sensitivity of $\mathrm{CH}_{4}$ emissions increased in the Molinia cores (Table II). In natural systems, acetoclastic methanogens are dominant over hydrogenotrophic methanogens (Kao-Kniffin et al., 2010). However, as reported in the latter study, graminoid soils are colonized primarily by hydrogenotrophic metabolisms. These two methanogenesis pathways require different levels of energy: $195 \mathrm{~kJ} \mathrm{~mol}^{-1}$ for hydrogenotrophic methanogenesis and $50 \mathrm{~kJ} \mathrm{~mol}^{-1}$ for acetoclastic methanogenesis (Beer and Blodau, 2007). Thus the increased temperature sensitivity under Molinia caerulea could reflect the promotion of hydrogenotrophic communities.

ER, $\mathrm{CH}_{4}$ emissions and [DOC] were correlated to WTL and soil temperature (Table II). Increased soil temperature enhanced exponentially these three C-fluxes under both plant 
communities (Fig 2). Soil temperature explained the higher amount of variability compared to the WTL, even for $\mathrm{CH}_{4}$ emissions. Such weak correlation with the WTL could also be due to the little WTL variation over the experiment. Our best fit between ER and temperature differed with the vegetation: ER in Sphagnum cores was more correlated to soil temperature at $5 \mathrm{~cm}$, whereas with Molinia caerulea ER was more influenced by soil temperature at $20 \mathrm{~cm}$ (Table II; Figure 2a). Sphagnum photosynthesis occurs in the first centimeters of the peat profile, whereas root exudates excreted by Molinia could stimulate microbial activity deeper in the peat profile. These physiological differences between Sphagnum and Molinia may explain the best fit observed for ER and also for $\mathrm{CH}_{4}$ emission and [DOC] (Table II).

In conclusion, both biotic (vegetation cover) and abiotic (mainly temperature) factors control $\mathrm{CO}_{2}$ and $\mathrm{CH}_{4}$ emissions and [DOC] in peat mesocosms. Molinia caerulea can deliver labile $\mathrm{C}$ stimulating microbial activity and promoting DOC consumption and $\mathrm{CO}_{2}$ and $\mathrm{CH}_{4}$ emissions. The increase in soil temperature enhanced [DOC] as well as $\mathrm{CO}_{2}$ and $\mathrm{CH}_{4}$ emissions. Moreover, our findings demonstrate that the two controlling factors interact and that vegetation modification changes the C-fluxes' sensitivities to temperature. Under global change, Cdynamics in peatlands are thus subjected to many alterations through plant community modification. This study advocates taking vegetation change into account in global models with a concomitant variation in the temperature sensitivity.

\section{Acknowledgements}

This paper is a contribution to the research conducted in the Labex VOLTAIRE (ANR10-LABX-100-01). The authors would like to thank X. Yin, G. Belot, A. Menneguerre for their contribution to gas measurements, P. Jacquet and C. Robert for their assistance in SPIRIT maintenance and N. Lothier for DOC analysis. We also thank E. Rowley-Jolivet for revision of the English version.

\section{References}


Armstrong, A., Waldron, S., Ostle, N. J., Richardson, H., Whitaker, J., 2015. Biotic and abiotic factors interact to regulate northern peatland carbon cycling. Ecosystems 18(8), 13951409.

Basiliko, N., Stewart, H., Roulet, N. T., Moore, T. R., 2012. Do root exudates enhance peat decomposition?. Geomicrobiology Journal 29(4), 374-378.

Beer, J., Blodau, C., 2007. Transport and thermodynamics constrain belowground carbon turnover in a northern peatland. Geochimica et Cosmochimica Acta 71(12), 2989-3002.

Buttler, A., Robroek, B. J., Laggoun-Défarge, F., Jassey, V. E., Pochelon, C., Bernard, G., Delarue, F., Gogo, S., Mariotte, P., Mitchell, E. A. D., Bragazza, L., 2015. Experimental warming interacts with soil moisture to discriminate plant responses in an ombrotrophic peatland. Journal of Vegetation Science 26(5), 964-974.

Clark, J., Ashley, D., Wagner, M., Chapman, P., Lane, S., Evans, C., Heathwaite, A., 2009. Increased temperature sensitivity of net DOC production from ombrotrophic peat due to water table draw-down. Global Change Biology 15(4), 794-807.

D’Angelo, B., Gogo, S., Laggoun-Défarge, F., Le Moing, F., Jégou F., Guimbaud C., 2016. Soil temperature synchronization improves representation of diel variability of ecosystem respiration in Sphagnum peatlands. Agricultural and Forest Meteorology 223, 95-102.

Davidson, E. A., Janssens, I. A., 2006. Temperature sensitivity of soil carbon decomposition and feedbacks to climate change. Nature 440(7081), 165-173.

Dieleman, C., Branfireun, B., McLaughlin, J., Lindo, Z., 2015. Climate change drives a shift in peatland ecosystem plant community: Implications for ecosystem function and stability. Global Change Biology 21(1), 388-395.

Fenner, N., Ostle, N. J., McNamara, N., Sparks, T., Harmens, H., Reynolds, B., Freeman, C., 2007. Elevated $\mathrm{CO}_{2}$ effects on peatland plant community carbon dynamics and DOC production. Ecosystems 10(4), 635-647. 
Freeman, C., Evans, C. D., Monteith, D. T., Reynolds, B., Fenner, N., 2001. Export of organic carbon from peat soils. Nature 412(6849), 785-785.

Freeman, C., Fenner, N., Ostle, N. J., Kang, H., Dowrick, D. J., Reynolds, B., Lock, M.A., Sleep, D., Hughes, S., Hudson, J., 2004. Export of dissolved organic carbon from peatlands under elevated carbon dioxide levels. Nature 430(6996), 195-198.

Gogo, S., Laggoun-Défarge, F., Delarue, F., \& Lottier, N., 2011. Invasion of a Sphagnumpeatland by Betula spp and Molinia caerulea impacts organic matter biochemistry. Implications for carbon and nutrient cycling. Biogeochemistry 106(1), 53-69.

Gorham, E., 1991. Northern peatlands: role in the carbon cycle and probable responses to climatic warming. Ecological Applications 1, 182-185.

Guimbaud, C., Catoire, V., Gogo, S., Robert, C., Chartier, M., Laggoun-Défarge, F., Grossel, A., Albéric, P., Pomathiod, L., Nicoullaud, B., Richard, G., 2011. A portable infrared laser spectrometer for flux measurements of trace gases at the geosphere-atmosphere interface. Measurement Science and Technology 22(7), 075601.

Kao-Kniffin, J., Freyre, D. S., \& Balser, T. C., 2010. Methane dynamics across wetland plant species. Aquatic Botany 93(2), 107-113.

Koelbener, A., Ström, L., Edwards, P. J., Venterink, H. O., 2010. Plant species from mesotrophic wetlands cause relatively high methane emissions from peat soil. Plant and Soil 326(1-2), 147-158.

Limpens, J., Berendse, F., Blodau, C., Canadell, J., Freeman, C., Holden, J., Roulet, N., Rydin, H., Schaepman-Strub, G., 2008. Peatlands and the carbon cycle: from local processes to global implications - a synthesis. Biogeosciences 5(5), 1475-1491.

Pypker, T., Moore, P., Waddington, J., Hribljan, J., Chimner, R., 2013. Shifting environmental controls on $\mathrm{CH}_{4}$ fluxes in a sub-boreal peatland. Biogeosciences 10(12), 7971-7981. 
Saarnio, S., Wittenmayer, L., Merbach, W., 2004. Rhizospheric exudation of Eriophorum vaginatum L.- potential link to methanogenesis. Plant and Soil 267(1-2), 343-355.

Schimel, J. P., 1995. Plant transport and methane production as controls on methane flux from arctic wet meadow tundra. Biogeochemistry 28(3), 183-200.

Ström, L., Mastepanov, M., \& Christensen, T. R., 2005. Species-specific effects of vascular plants on carbon turnover and methane emissions from wetlands. Biogeochemistry $75(1), 65-82$.

Tomassen, H., Smolders, A. J., Lamers, L. P., Roelofs, J. G., 2003. Stimulated growth of Betula pubescens and Molinia caerulea on ombrotrophic bogs: role of high levels of atmospheric nitrogen deposition. Journal of Ecology 91(3), 357-370.

Turunen, J., Tomppo, E., Toloken, K., Reinikainen, A., 2002. Estimating carbon accumulation rates of undrained mires in Finland-application to boreal and subarctic regions. The Holocene 12, 69-80. 


\section{Tables}

Table I: Mean values of 12 months' measurements of Ecosystem Respiration (ER), $\mathrm{CH}_{4}$ emissions $\left(\mathrm{CH}_{4}\right)$, Dissolved Organic Carbon (DOC), Water Table Level (WTL), photosynthetically active radiation (PAR) and air (Ta) and soil temperature (Ts) in Molinia and Sphagnum cores. Significance levels of one way ANOVAs with repeated measured are expressed as $* p<0.05, * * p<0.01, * * * p<0.001(n=6)$.

\begin{tabular}{|c|c|c|c|c|}
\hline & \multicolumn{2}{|c|}{ Mean } & \multirow{2}{*}{$\begin{array}{l}\text { Molinia / } \\
\text { Sphagnum }\end{array}$} & \multirow{2}{*}{$\mathrm{P}$} \\
\hline & Molinia & Sphagnum & & \\
\hline \multicolumn{5}{|l|}{ GHG fluxes } \\
\hline $\mathrm{ER}\left(\mu \mathrm{mol} \mathrm{m} \mathrm{m}^{-2} \mathrm{~s}^{-1}\right)$ & 2.39 & 0.99 & 2.39 & $* * *$ \\
\hline $\mathrm{CH}_{4}\left(\mu \mathrm{mol} \mathrm{m} \mathrm{m}^{-2} \mathrm{~s}^{-1}\right)$ & 0.094 & 0.030 & 3.14 & $*$ \\
\hline \multicolumn{5}{|l|}{ Water compartment } \\
\hline $\mathrm{DOC}\left(\mathrm{mg} \mathrm{L}^{-1}\right)$ & 31.9 & 55.7 & 0.57 & $* * *$ \\
\hline WTL $(\mathrm{cm})$ & -7.04 & -4.58 & 1.54 & $* * *$ \\
\hline \multicolumn{5}{|l|}{ Environmental parameters } \\
\hline $\operatorname{PAR}\left(\mu \mathrm{mol} \mathrm{m} \mathrm{m}^{-2} \mathrm{~s}^{-1}\right)$ & 711 & 741 & 0.96 & \\
\hline $\mathrm{Ta}\left({ }^{\circ} \mathrm{C}\right)$ & 12.0 & 12.1 & 0.99 & \\
\hline Ts at $5 \mathrm{~cm}\left({ }^{\circ} \mathrm{C}\right)$ & 13.1 & 13.1 & 1 & \\
\hline Ts at $20 \mathrm{~cm}\left({ }^{\circ} \mathrm{C}\right)$ & 13.7 & 13.9 & 0.99 & \\
\hline
\end{tabular}

Table II: Determination coefficient $\left(\mathrm{r}^{2}\right)$ of exponential regressions for mean values of 12 months' measurements of Ecosystem Respiration (ER), $\mathrm{CH}_{4}$ emissions $\left(\mathrm{CH}_{4}\right)$, Dissolved Organic Carbon (DOC) with Water Table Level, Air and Soil Temperature at 5 and $20 \mathrm{~cm}$. Bold numbers represent the highest determination coefficient for each variable in Sphagnum and Molinia cores. Significance correlation are expressed as ${ }^{-/} \mathrm{p}<0.05,-{ }^{-{ }^{++}} \mathrm{p}<0.01,{ }^{---/^{+++}} \mathrm{p}<0.001$. $\tau^{-}$represents a negative or positive relationship, respectively. 


\begin{tabular}{|c|c|c|c|c|c|c|c|}
\hline & \multirow{2}{*}{ Variables } & \multicolumn{2}{|c|}{$\begin{array}{l}\text { Determination coefficient } \\
\qquad\left(\mathrm{r}^{2}\right)\end{array}$} & \multicolumn{2}{|c|}{$\mathrm{Q}_{10}$} & \multicolumn{2}{|c|}{$\mathrm{Ea}$} \\
\hline & & Sphagnum & Molinia & Sphagnum & Molinia & Sphagnum & Molinia \\
\hline \multirow{3}{*}{$\begin{array}{c}\text { Water Table } \\
\text { Level }\end{array}$} & ER & $0.38^{---}$ & $0.23^{--}$ & & & & \\
\hline & $\mathrm{CH}_{4}$ & $0.49^{--}$ & $0.18^{--}$ & & & & \\
\hline & DOC & $0.12^{-}$ & $0.14^{-}$ & & & & \\
\hline \multirow{3}{*}{ Air Temperature } & ER & $0.72^{+++}$ & $0.60^{+++}$ & 3.75 & 2.58 & 92.2 & 65.7 \\
\hline & $\mathrm{CH}_{4}$ & 0.00 & 0.01 & 1.00 & 1.01 & 2.3 & 4.7 \\
\hline & DOC & $0.55^{+++}$ & $0.46^{+++}$ & 1.56 & 1.66 & 31.7 & 35.9 \\
\hline \multirow{3}{*}{$\begin{array}{c}\text { Soil Temperature } \\
\text { at } 5 \mathrm{~cm}\end{array}$} & ER & $\mathbf{0 . 7 6}^{+++}$ & $0.67^{+++}$ & 4.09 & 2.86 & 97.6 & 72.9 \\
\hline & $\mathrm{CH}_{4}$ & $0.68^{+++}$ & $0.86^{+++}$ & 5.61 & 7.61 & 119.4 & 140.2 \\
\hline & DOC & $0.64^{+++}$ & $0.60^{+++}$ & 1.68 & 1.91 & 36.0 & 44.5 \\
\hline \multirow{3}{*}{$\begin{array}{c}\text { Soil Temperature } \\
\text { at } 20 \mathrm{~cm}\end{array}$} & ER & $0.65^{+++}$ & $0.75^{+++}$ & 4.01 & 3.38 & 97.3 & 85.0 \\
\hline & $\mathrm{CH}_{4}$ & $0.59^{+++}$ & $0.88^{+++}$ & 4.05 & 9.13 & 94.6 & 153.1 \\
\hline & DOC & $0.37^{+++}$ & $\mathbf{0 . 7 0}^{+++}$ & 1.47 & 2.38 & 25.3 & 60.0 \\
\hline
\end{tabular}

\section{Figures}
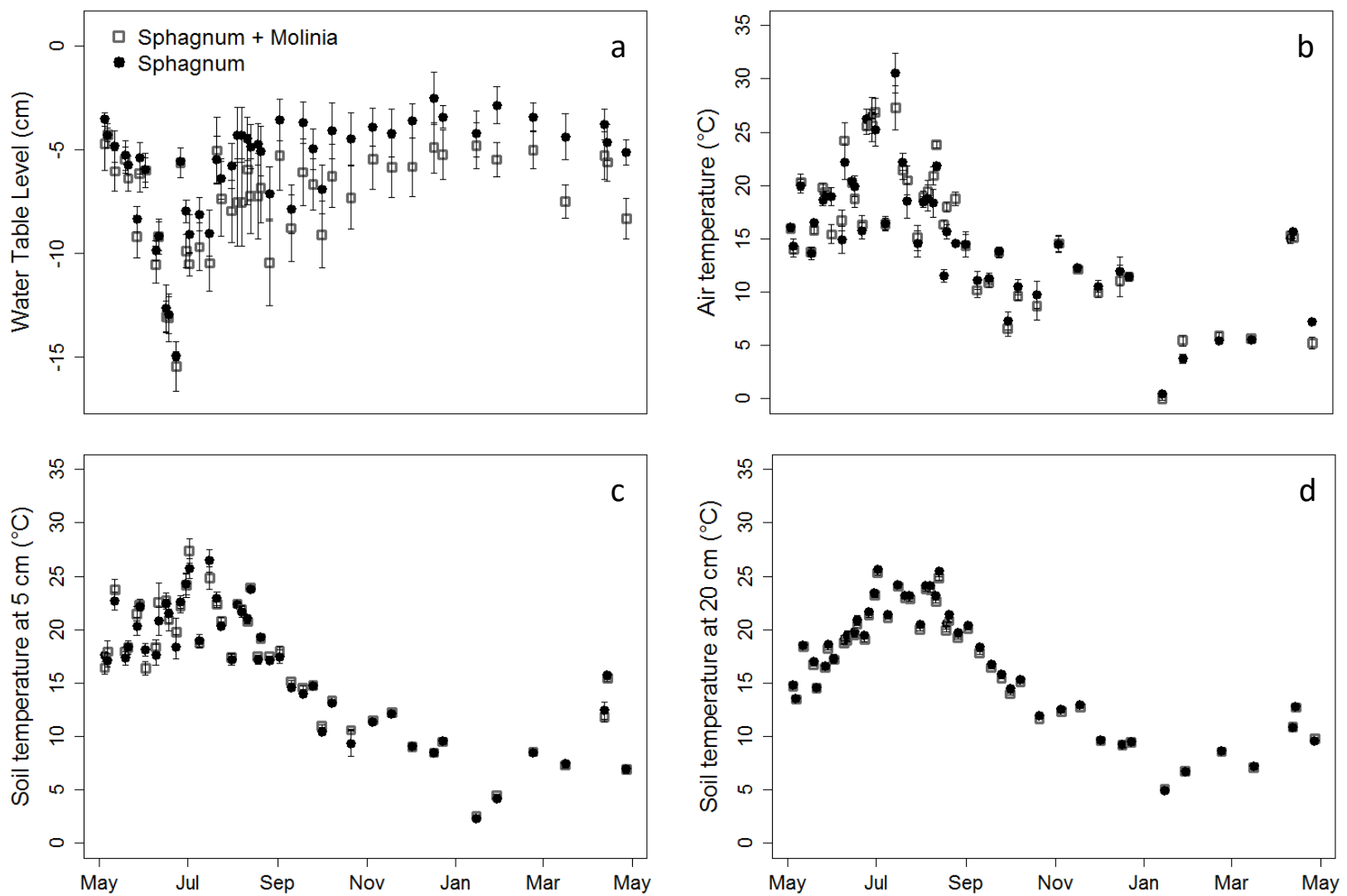

Figure 1: Time series of water table level (a), air (b) and soil temperature at 5 (c) and $20 \mathrm{~cm}$ (d) in Sphagnum and Molinia cores $( \pm$ SE, $n=6)$ from May 2015 to April 2016. Data were collected during greenhouse gas emission measurements. 

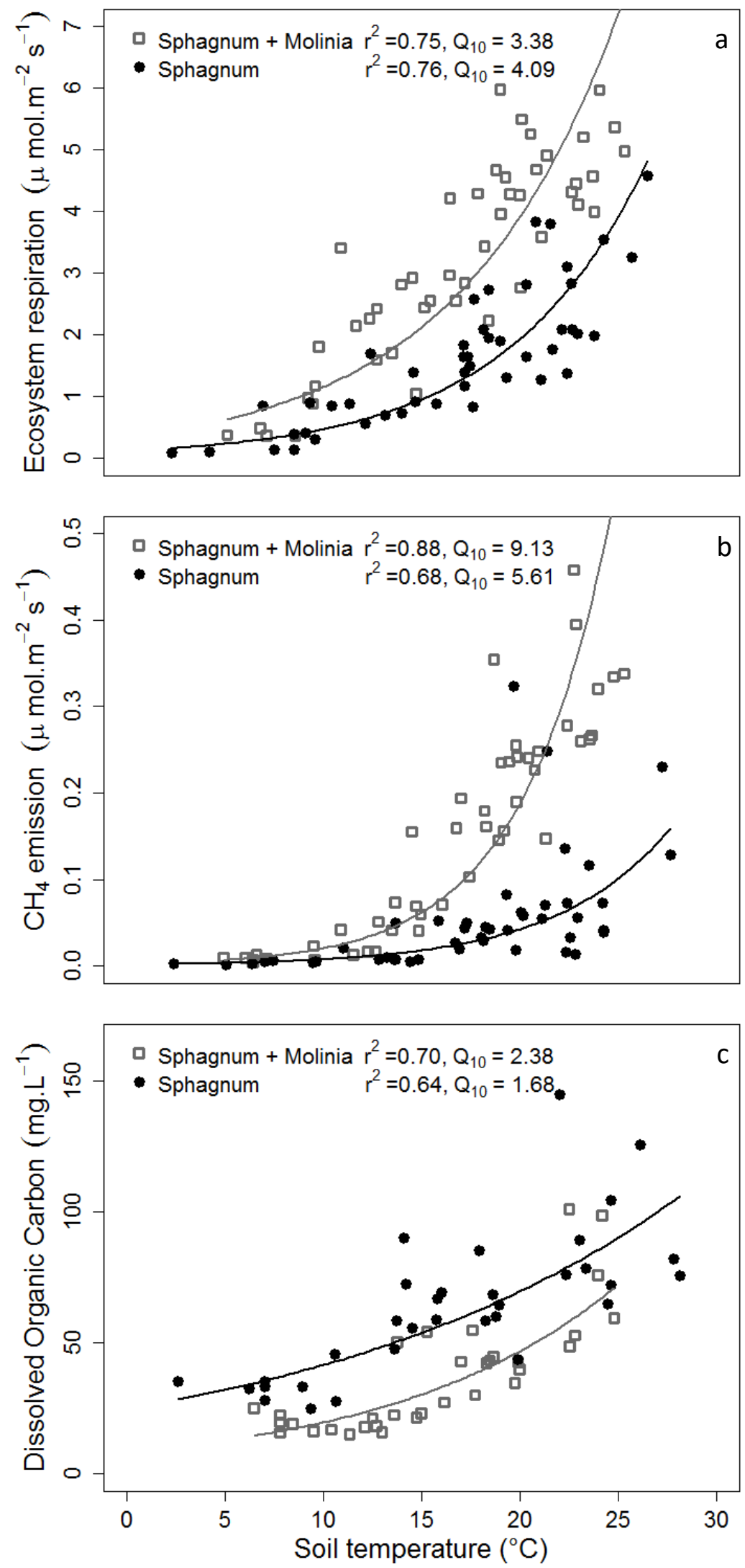

Figure 2: Exponential relationship between Ecosystem Respiration (a), $\mathrm{CH}_{4}$ emission (b), Dissolved Organic Carbon (c) and soil temperature at $5 \mathrm{~cm}$ for Sphagnum cores and at $20 \mathrm{~cm}$ for Molinia cores 


\section{Supplementary materials}

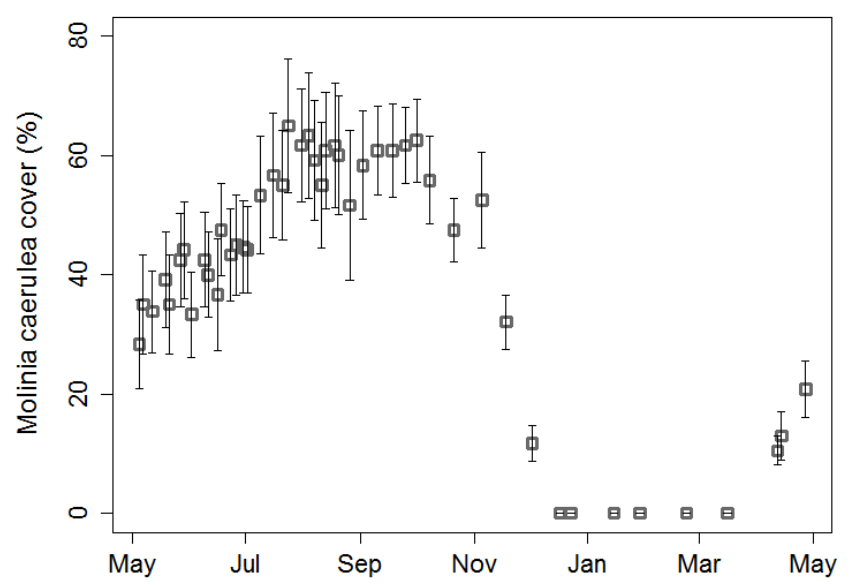

Figure 3: Time series of Molinia caerulea cover in Molinia cores $( \pm$ SE, $n=6)$ from May 2015 to April 2016. Data were collected during greenhouse gas emission measurements. 